\title{
Bonds, Bondholders Protection and Asset Allocation of Multimarket Funds
}

\author{
Thayse Machado Guimarães ${ }^{1}$ \\ thaysemg.adm@gmail.com | @0000-0002-1937-8017 \\ Rodrigo Fernandes Malaquias ${ }^{1}$ \\ rodrigofmalaquias@ufu.br | @0000-0002-7126-1051
}

\begin{abstract}
This paper aims to create a bondholders' protection index (BPI) and to investigate what the influence of this index would be on multimarket funds' allocation in corporate bonds. Understanding this relation is relevant because only about $1.36 \%$ of multimarket funds' portfolios correspond to debentures. This study advances the literature by covering a topic little discussed in a Brazilian context, proposing the creation of a BPI, which would be related to the number of automatic maturity clauses, which guarantee immediate payment to bondholders in cases of the rupture of a contract. This research comprised 926 debentures series issued in Brazil from 2009 to 2017, and 1,753 multimarket funds, which allocated some portfolios' percentage in these securities. In creating the BPI, we contemplated 15 restrictive clauses, which the most common correspond to negligent business performance, liquidation, dissolution and bankruptcy, and restrictions related to company structure. Moreover, we examined less common restrictive clauses as well, including indebtedness policy, shares issuance and amortization, and ratings downgrading. Regarding data analysis, we employed multiple linear regression models, with pooled estimators, applying the standard error correction by White's robust matrix (1980). The main results suggest that BPI positively effects multimarket funds' allocation in debentures. Furthermore, this influence is more intense in indentures with higher number of clauses with automatic maturity. Thus, this study contributes to literature about restrictive clauses, since it demonstrates that debentures' flexible and adaptable structure seems to be interesting for the main bondholders in Brazil.
\end{abstract}

\section{KEYWORDS}

bondholders' protection index, corporate bonds, multimarket funds, risk, corporate financing
${ }^{1}$ Universidade Federal de Uberlândia, Uberlândia, MG, Brasil 


\section{INTRODUCTION}

Corporate bonds are fundamental financing instruments for institutional investors (Liu, Dai, \& Wang, 2016) and mutual funds are one of the main debentures' subscribers in Brazil (Associação Brasileira das Entidades dos Mercados Financeiro e de Capitais [Brazilian Financial and Capital Markets Association], Capital Markets Bulletin, 2018; Paula, Faria Jr., 2012). They seem to be a safe investment option, due to the guarantee of creditors' payment, which involves the amount invested plus interest. However, when companies' managers opt for actions that increase investment risk, it can result in losses for bondholders (Kahan, 1995).

Thus, corporate bonds financing leads to agency conflict between shareholders/ managers and bondholders, which reduces firms' value (Saito, Sheng, \& Bandeira, 2007). Bondholders generally choose to protect themselves from managers' negligent performance, by means of indentures' restrictive clauses (Nash, Nette, \& Poulsen, 2003). This paper aims at creating a bondholders' protection index (BPI) and at investigating what is the influence of this index on multimarket funds allocation in corporate bonds.

Covenants are the cheapest way of mitigating potential issues in the relationship between shareholders and bondholders (Jerzemowska, 2006) and they assure bondholders the early debentures' maturity in circumstances where the rules are not followed (Saito, Sheng, \& Bandeira, 2007). In regards to our contribution to the literature, we point out that this paper proposes the creation of a BPI, which includes 15 restrictive clauses, utilizing the works of Billet, King and Mauer (2007) and Silva, Saito and Barbi (2013). Moreover, this study shows the interactions of this index with "automatic payment" clauses, which refer to the guarantee of immediate payment for bondholders in cases of the violating of any clauses.

Especially in a Brazilian case, BPI is crucial, because the majority of debentures (78\%), from 2011 to 2017, were issued without bondholders preferences concerning issuing companies' assets, in other words, they were unsecured corporate bonds (ANBIMA, Capital Markets Bulletin, 2018).

Debentures are one of the main assets used by companies for raising funds in the domestic market (Paiva \& Savoia, 2009). The volume obtained through these debt securities is mostly used as working capital, as well as for refinancing liabilities, and debts restructuration (ANBIMA, Capital Markets Bulletin, 2018).

From 2009 to 2017 , debenture issues volume grew by $95 \%$, and, in 2017 , almost $\mathrm{R} \$ 88$ billion were issued in debentures, which corresponds to $40 \%$ of the Brazilian capital market. In the same period, institutional investors got around $41 \%$ of debentures issued, especially in 2017 , when they were the most representative bondholders, holding $61 \%$ of all issued corporate bonds (ANBIMA, Capital Markets Bulletin, 2018).

The Brazilian fund industry is the world's tenth largest, holding 16,000 funds in 2017, with funding of roughly R $\$ 4.1$ trillion, which represented 3\% of the world's net worth (ANBIMA, Consolidated Historical of Investment Funds, 2018).

As related to invested volume, investment funds in Brazil have been the main choice with their industry growing about $23 \%$ annually since 1995 . Moreover, only in 2008, a period of global financial crisis, did the volume show a decrease (Bono Milan \& Eid Junior, 2017).

This study focuses on multimarket funds, which are the second largest class, in relation to the Brazilian funds industry's net worth, with a $21.1 \%$ average portfolio' share. Furthermore, this is the class which involves, approximately, $50 \%$ of the total numbers for institutional investors (ANBIMA, Consolidated Historical of Investment Funds, 2018). 
BBR

17

134

We highlight that this paper contributes to corporate bonds literature, because it is more common to discuss this subject in developed countries (International Organization of Securities Comission, 2002). Also, restrictive clauses are not well known and / or investigated in both national and international literatures (Bradley \& Roberts, 2015). Although there have been studies (Smith \& Warner, 1979; Billet, King, \& Mauer, 2007; Saito, Sheng, \& Bandeira, 2007) that analyze ways of mitigating agency conflicts in debt contracts, no papers were identified that address the relationship of these clauses to multimarket funds allocation in debentures.

Although there was a growth of approximately $95 \%$ in the issuance of debt securities in the Brazilian capital market from 2009 to 2017, only about 3.52\% of mutual funds' portfolios corresponded to corporate bonds (ANBIMA, Consolidated Historical of Investment Funds, 2018). Therefore, it is relevant to understand what influences the allocation of multimarket funds in debentures.

Considering the aforementioned, this paper's hypothesis concerns the positive influence of the bondholders protection index on the percentage that multimarket funds allocate in debentures. Results of this study responded to this hypothesis, since they showed that the expected relationship was statistically significant at the $1 \%$ level. Thus, this study advances the literature by indicating that, as bondholders' protection grows, the allocation of multimarket funds in debentures also increases.

We point out the relevance of this study for managers and fund investors, because it focuses on bondholders protection. It is also important for regulatory agencies, such as the Brazilian Financial and Capital Market Association (ANBIMA), especially in projects such as the standardization of debentures' indentures.

This paper is organized as follows: Section 2 comprises the literature review and the hypothesis. Section 3 includes this study's delimitations, variables selection and econometric models development. Section 4 presents sample's definition and the descriptive statistics. Section 5 discusses main results, and section 6 concludes the study with some remarks and future research suggestions.

\section{LITERATURE REVIEW}

\subsection{Agency Theory}

The agency theory admits conflicts between different individuals who, in the context of debentures, correspond to disagreements between bondholders, shareholders, and managers. Thus, covenants are effective instruments in mitigating agency problems linked to debt contracts (Smith \& Warner, 1979).

According to Jensen and Meckling (1976), individuals' rights are determined by signed contracts, and the agency relationship originates from established contracts between one or more people. That is, the principal hires an agent in a competitive market and can choose the way of this agent will perform, but principal cannot force this agent to act in accordance with what he expects (Christensen \& Feltham, 2005). Hence, due to property rights' reduction, a manager's effort for maximizing enterprises' value can also be diminished (Jensen \& Meckling, 1976).

Since both contract parties, principal and agent, aim to maximize their benefits, it cannot be expected that an agent will always act in accordance with a principal's interests, but the principal may limit the agent's behavior with appropriate incentives. Therefore, it is impossible for the agent to perform at an optimal level, from principal's point of view, without any involved cost. 
Thus, the main agency costs can be classified as follows: (i) monitoring costs, (ii) contractual guarantees cost; and (iii) residual cost (Jensen \& Meckling, 1976).

It is not usual for large companies to be financed almost entirely by outside capital because, in the face of a financial structure mostly composed of creditors' capital, the owner-manager can be encouraged to engage in higher risk activities. Hence, if decisions are successful, they can generate higher personal compensation, but if they are not, creditors will assume most of the costs (Jensen \& Meckling, 1976).

For Sheng (2005) "all corporate debt issuances provokes conflicts between bondholders and shareholders, also known as moral hazard.” (p. 61) Moral hazard, as presented by Beaver (1998), results from information asymmetry, which enables agents to have inside information for acting in accordance with their own interests, thus expropriating the principal.

The moral hazard associated with conflicts between bondholders and shareholders is related to shareholders' detrimental behavior in regards to dividends payment, new debtsm or even changes in company's policy investment (Smith \& Warner, 1979).

For bondholders, agency costs correspond to monitoring and the possibility of debt contract renegotiation. On one hand, the lack of monitoring for bondholders can encourage managers to reduce creditors' wealth, which leads to credit quality deterioration. Hence, bondholders may require a higher interest rate to offset these risks (Saito, Sheng, \& Bandeira, 2007; Ghouma, 2017).

On the other hand, if there is a credit quality improvement, issuing companies may choose to renegotiate the debt agreement, or even modify new issued debentures' indentures. Thus, this new contract can involve additional costs, which are feasible if benefits to one of the parties were sufficient for justifying them (Saito, Sheng, \& Bandeira, 2007).

Restrictive clauses in debentures' contracts are significantly influenced by managerial performance, and indentures are efficient for evaluating different risks associated to managerial fraud. Hence, covenants are relevant, since they correspond to an opportunity for reducing bondholders' agency cost and financing cost (Chava, Kumar, \& Warga, 2010).

Moreover, covenants are common features in debt contracts and they antecipate potential managers and shareholders' opportunistic performance by imposing limitations on bond issues which inhibit bondholders's wealth transfer (Bradley \& Roberts, 2015; Devos, Rahman, \& Tsang, 2017).

Thus, in the Brazilian reality, one way to mitigate these conflicts is the adoption of standardized indentures, which are easier to understand, because they have simpler clauses. So, bondholders have their rights protected by fiduciary agents who monitor companies' activities (Sheng, 2005).

\section{2. НYPOTHESIS}

The literature about covenants show situations in which these clauses grant shareholders and bondholders conflicts mitigation (Smith \& Warner, 1979; Billet, King, \& Mauer, 2007). There must be a balance between these clauses, since, on the creditors side, there are those that correspond to monitoring and deb contract renegotiation while, on the issuing companies side, those that can influence decision making and investment policy (Saito, Sheng, \& Bandeira, 2007).

Both bondholders and managers are incentivized to maintain covenants, and it is feasible for creditors to support the cost of drafting clauses and monitoring managers' actions until the moment the marginal cost of these activities will be the same as marginal benefits obtained with this contract elaboration (Jensen \& Meckling, 1976). 
BBR

17

136

Covenants are not uncommon in debt issues (Jensen \& Meckling, 1976), they have been a typical feature for over 100 years, although standardized contracts were few at the time (Smith \& Warner, 1979). These clauses need to be detailed enough to cover companies' operational aspects, including projects' risk. Therefore, standardized debt securities contracts are suggested, especially in incomplete markets (Sheng, 2005).

Smith and Warner (1979) considered 87 public debt issues from January 1974 to December 1975 and noted that opportunity costs associated with restrictive clauses were substantial because, although they involved additional drafting costs, they reduced agency conflict's costs.

Covenants reduce debt cost and increase firms value. However, this does not mean that these clauses, considered optimal at the time of issuance, will remain relevant over time. Since these clauses can be amended, with the approval of creditors, bondholders coordinate their actions to modify or disapprove disadvantageous changes, in view of seeking gains with these indentures' changes (Kahan \& Tuchman, 1993).

Debentures are flexible and adaptable in accordance with bondholders' well-being. In Brazil, there are more debentures that relate to floating interest rates rather than to inflation, there are less restrictive (or unrestricted) clauses associated with financing, whereas the most restrictive clauses concern changes in companies control, and the lack of guarantees (Saito, Sheng, \& Bandeira, 2007).

Companies adopt restrictive clauses and short-term debt for mitigating shareholder and bondholder disputes. An analysis of more than 50 covenants for 15,000 issued debentures by non-financial corporations, from 1960 to 2003, revealed that these clauses have grown over the years, especially in environments with greater leverage and growth opportunity. These clauses decreased with the increment of short-term debt (Billet, King, \& Mauer, 2007).

Concerning 159 issued debentures in Brazil from 2000 to 2009 by 82 different companies, it is possible to corroborate this evidence, since the main results of this study show that restrictive clauses and short-term financing are alternative tools for minimizing agency conflict between shareholders and creditors. Moreover, due to these covenants, companies with growth possibilities are more likely to switch from short to long-term financing. In this way, covenants tend not to restrict growth opportunities (Silva, Saito, \& Barbi, 2013).

According to the aforementioned studies, debentures in Brazil are more flexible than other financing alternatives, and can offer different compensation rates, re-contracting clauses with lower transaction costs, and their deeds can involve call and put options (Saito, Sheng, \& Flag, 2007). Covenants number and types depend on the level of agency conflicts, and on costs and benefits associated with restrictive clauses (Qi, Roth, \& Wald, 2011). In addition, bondholders generally choose to protect themselves against the negligent performance of managers by means of debentures' restrictive clauses (Nash, Nette \& Poulsen, 2003). Based on this reasoning, our hypothesis corresponds to:

$\mathbf{H}_{1}$ : bondholder's protection index is positively related to the percentage that multimarket funds allocate in corporate bonds. 


\subsection{DATA}

The sample period starts in 2009. The Brazilian investment funds industry has increased, since 2009 at an average rate of increase of about 9.1\% until 2017 (ANBIMA, Consolidated Historical of Investment Funds, 2018). Moreover, we were able to collect information related to portfolio composition of investment funds starting in 2009, and in such year there was the publication of ICVM 476, that allowed an expansion in the emission of corporate bontds and operations in the capital market (Carvalho, 2017).

The sample period ends in 2017 since it is the last year in which data was available to download when we started this research. The year of 2017 also showed a large inflow of resources through corporate bonds, about BR $\$ 88$ billion and the investment funds industry showed an amout of total net assets close to BR $\$ 4.1$ billion.

The analysis of corporate bonds was annual and each debentures' series was evaluated considering its issue date too its due date. The data collection involved several different databases (ANBIMA website, CVM website and Economatica ${ }^{\oplus}$ Database) and comprises 23,480 observations.

\subsection{Variables of THe STUdy}

The dependent variable of this study is the multimarket funds interest for corporate bonds. This variable was estimated based on the value that each multimarket funds invested in each corporate bond over the sample period, as described in Chart 1 . The value invested by the fund was weighted by its respective total net assets.

Chart 1

Variables of the Study

\begin{tabular}{|c|c|c|c|c|}
\hline Variable & & Description & Measurement & Source \\
\hline Dependent & $\%$ FUND & $\begin{array}{l}\text { Percentage of each } \\
\text { multimartket fund } \\
\text { portfolio invested in } \\
\text { each corporate bond }\end{array}$ & $\begin{array}{c}\text { FFUND }_{\mathrm{ijt}}= \\
\frac{\text { Value (in BR\$) that the fund } i \text { invested in the bond } j \text { in the period } t}{\text { Total Net Asset (in BR\$) of the fund } i \text { in the period } t}\end{array}$ & $(1) ;(2)$ \\
\hline & BPI & $\begin{array}{l}\text { Bondholders' } \\
\text { Protection Index }\end{array}$ & $\mathrm{BP}_{i}=\frac{\text { Sum of } 15 \text { Covenants }}{15}$ & (3) \\
\hline Independent & BPI * AM & $\begin{array}{l}\text { Interaction between } \\
\text { BPI and the number } \\
\text { of "automatic } \\
\text { maturity" clauses }\end{array}$ & $\begin{array}{l}\text { This is the interaction between BPI and AM, in } \\
\text { which AM is a dummy variable that receives } 1 \\
\text { for debentures' indentures with the large number } \\
\text { of "automatic maturity" clauses. We used two } \\
\text { measures of position to define the "large number" } \\
\text { of clauses: the median and the third quartile of the } \\
\text { number of automatic maturity clauses. }\end{array}$ & (3) \\
\hline
\end{tabular}

Note. Data sources: (1) Economatica ; (2) CVM; (3) Debentures ANBIMA.

Source: research database. 
BBR

17

138

As indicated in Chart 1, the independent variable is BPI. This index was calculated based on Billet, King and Mauer (2007), and Silva, Saito and Barbi (2013) and it also involves restrictive clauses and clauses that indicate what companies need to follow. The advancement of this research is to consider the interaction of BPI with the number of "automatic maturity" clauses available in the debentures' indentures. This interaction was done through the creation of a dummy variable that receives 1 for debentures' indentures that have a large number of "automatic maturity" clauses when compared to the other indentures. As the cutpoint, we used two measures of position: the median and the third quartile of the number of automatic maturity clauses. The third quartile was considered as an evaluation of the BPI behavior in the presence of a large number of automatic maturity clauses.

Therefore, the BPI comprises the following restrictive clauses: dividends restrictions; capital reduction; liquidation, dissolution and bankruptcy; modification of business essence; modification in the company's structure; modification in the control; assets sale or transference; negligence; legal obligations and environmental permits; financial indexes; investments; leverage; stocks emission or amortization; rating classification; and merger, split and incorporation. Each one of these 15 covenants is a dummy variable that receives 1 when the indenture has the respective clause and 0 if it does not. The bondholders' protection index considers the sum of the 15 covenants, divided by 15 , which is the maximum score that each document can achieve. Therefore, the BPI varies from 0 to 1 , and values next to 1 indicate indentures with higher number of clauses for bondholder's protection.

Regarding control variables, we considered the characteristics of corporate bonds, the features of companies, and the characteristics of multimarket funds, following evidence from previous research on corporate bonds and investment funds. Chart 2 contains the description of such variables.

Chart 2

Control Variables

\begin{tabular}{|c|c|c|c|c|c|}
\hline & & Description & Measurement & Reference & Source \\
\hline \multirow{5}{*}{$\begin{array}{l}\text { Corporate } \\
\text { Bonds }\end{array}$} & REST & $\begin{array}{l}\text { Corporate Bonds } \\
\text { issued with } \\
\text { restrict efforts }\end{array}$ & $\begin{array}{l}\text { Dummy, } 1 \text { for indentures issued } \\
\text { with restrict efforts following the } \\
\text { instruction CVM } 476 \text { and } 0 \text { for the } \\
\text { other cases }\end{array}$ & \multirow[b]{2}{*}{$\begin{array}{l}\text { Konraht and } \\
\text { Vicente (2017) }\end{array}$} & \multirow{5}{*}{ (3) } \\
\hline & INCENT & $\begin{array}{l}\text { Incentivized } \\
\text { Corporate Bonds }\end{array}$ & $\begin{array}{l}\text { Dummy, } 1 \text { for incentivized corporate } \\
\text { bonds and } 0 \text { for the other cases }\end{array}$ & & \\
\hline & REAL & $\begin{array}{l}\text { Kind of } \\
\text { Corporate Bonds } \\
\text { Guarantee }\end{array}$ & $\begin{array}{l}\text { Dummy, } 1 \text { for indentures with the } \\
\text { guarantee is real and } 0 \text { for the other } \\
\text { cases }\end{array}$ & $\begin{array}{l}\text { Bragança, Pessoa } \\
\text { and Souza } \\
(2015)\end{array}$ & \\
\hline & MAT & $\begin{array}{l}\text { Corporate Bonds } \\
\text { Maturity }\end{array}$ & $\begin{array}{l}\text { Dummy, } 1 \text { for indentures with } \\
\text { maturity equals or lower than three } \\
\text { years and } 0 \text { for the other cases }\end{array}$ & $\begin{array}{l}\text { Billet, King and } \\
\text { Mauer (2007) } \\
\text { ANBIMA }\end{array}$ & \\
\hline & RATE & $\begin{array}{l}\text { Rate of } \\
\text { Remuneration of } \\
\text { Corporate Bonds }\end{array}$ & $\begin{array}{l}\text { Bonds Indexers: Dummy, } 1 \text { for } \\
\text { bonds indexed as a percentage of } \\
\text { ID (interbank deposits) rate and } 0 \\
\text { for the other cases (IPCA and other } \\
\text { rates) }\end{array}$ & $\begin{array}{l}\text { ANBIMA } \\
(2018)\end{array}$ & \\
\hline
\end{tabular}




\begin{tabular}{|c|c|c|c|c|c|}
\hline Varia & & Description & Measurement & Reference & Source \\
\hline \multirow{5}{*}{ Companies } & SIZE & Company Size & $\begin{array}{l}\mathrm{SIZE}_{\mathrm{it}}=\mathrm{NL}(\text { Market Value) } \\
\text { where: "nl" represents the natural } \\
\text { logarithmic and Market Value } \\
\text { representes the product between } \\
\text { the stock's price and the number of } \\
\text { stocks of the company }\end{array}$ & \multirow{4}{*}{$\begin{array}{l}\text { Fama and } \\
\text { French }(2015)^{*} \\
\text { Sobrinho } \\
(2016)\end{array}$} & \multirow{4}{*}{ (1) } \\
\hline & BTM & Book-to-market & BTM $_{i t}=\frac{\text { Book Value }}{\text { Market Value }}$ & & \\
\hline & PROF & $\begin{array}{l}\text { Return over the } \\
\text { Net Worth }\end{array}$ & PROF $_{i t} \frac{\text { Net Profit }}{\text { Net Worth }}$ & & \\
\hline & INV & Investment & $\mathrm{INV}_{i t}=\frac{\text { Total Asset } \mathrm{t}_{-1}-\text { Total Asset } \mathrm{t}_{-2}}{\text { Total Asset } \mathrm{t}_{-2}}$ & & \\
\hline & NM & B3's New Market & $\begin{array}{l}\text { Companies listed at the New Market } \\
\text { of B3 }\end{array}$ & $\begin{array}{l}\text { Ripamonti and } \\
\text { Kayo (2016) }\end{array}$ & $(4)$ \\
\hline \multirow{10}{*}{$\begin{array}{l}\text { Multimarket } \\
\text { Funds }\end{array}$} & NL(TNA) & Fund's Size & $\begin{array}{l}\text { NL(TNA) = Natural Logarithmic of } \\
\text { Total Net Assets }\end{array}$ & \multirow{2}{*}{$\begin{array}{l}\text { Amin and Kat } \\
(2003)\end{array}$} & \multirow{10}{*}{$\begin{array}{l}(1) \text {; } \\
(2)\end{array}$} \\
\hline & FoF & Funds of Funds & $\begin{array}{l}\text { Dummy, } 1 \text { for funds of funds and } 0 \\
\text { for the other cases }\end{array}$ & & \\
\hline & \multirow{3}{*}{ MGMFee } & \multirow{3}{*}{$\begin{array}{l}\text { Management } \\
\text { Fee, charged as a } \\
\text { remuneration by } \\
\text { the management } \\
\text { services }\end{array}$} & \multirow{3}{*}{$\begin{array}{l}\text { Represents the maximum } \\
\text { management fee charged by the } \\
\text { fund in the year (in \%) }\end{array}$} & Eid Jr. (2006) & \\
\hline & & & & $\begin{array}{l}\text { Milani and } \\
\text { Ceretta (2013) }\end{array}$ & \\
\hline & & & & Malaquias and & \\
\hline & \multirow{4}{*}{ PERFFee } & \multirow{4}{*}{$\begin{array}{l}\text { Performance Fee, } \\
\text { charged when the } \\
\text { profitability of } \\
\text { the fund is higher } \\
\text { than a benchmark } \\
\text { previously } \\
\text { established }\end{array}$} & \multirow{4}{*}{$\begin{array}{l}\text { Dummy, } 1 \text { for funds that charge } \\
\text { performance fees and } 0 \text { for the other } \\
\text { cases }\end{array}$} & Eid Jr. (2014) & \\
\hline & & & & $\begin{array}{l}\text { Bono Milan and } \\
\text { Eid Jr. (2014) }\end{array}$ & \\
\hline & & & & $\begin{array}{l}\text { Malaquias and } \\
\text { Mamede (2015) }\end{array}$ & \\
\hline & & & & Malaquias and & \\
\hline & AGE & Fund's Age & $\begin{array}{l}\text { Fund's Age, in years, until December } \\
31,2017\end{array}$ & Pontes (2018) & \\
\hline
\end{tabular}

Note. Data Souces: (1) Economatica ${ }^{\circledR}$; (2) CVM; (3) Debentures ANBIMA; (4) B3 Website. * In the study of Fama and French (2015), the size was measured by the difference between the average return of stocks from small firms and the average returno $f$ stocks from large firms. However, as we do not construct factors in this study, we consider the natural logarithmic of the market value of each firm as a proxy for its size.

Source: research database.

Our analysis also includes a variable for the crisis period, which is a dummy variable that receives 1 for the years 2015 and 2016 and 0 for the other years. In the years of 2015 and 2016, Brazil experienced its worst accumulated recession since 1948, with GDP falling by 7.2\% (Saraiva $\&$ Sales, 2017). In this time period, we also observed a reduction in the number of domestic emissions in the Brazilian capital market and, particularly in 2015, a negative net inflow in the investment funds (fixed income, stocks and multimarkets). 
BBR

17

140

\subsection{Econometric Model}

The database of this study comprises cross sectional data (i) related to the acquisition of corporate bonds by different multimarket funds over a time series ( $\mathrm{t}$ ), from January 2009 to December 2017. Therefore, we employed a regression model with panel data (Greene, 2002) as described in Equation 1.

$$
\% \mathrm{FUND}_{\mathrm{ijt}}=\beta_{0}+\beta_{1} \mathrm{BPI}_{\mathrm{j}}+\beta_{2} \mathrm{BPI}_{\mathrm{j}}^{*} \mathrm{AM}+\beta_{3} \mathrm{CVB}_{\mathrm{j}}+\beta_{4} \mathrm{CVC}_{\mathrm{et}}+\beta_{5} \mathrm{CVF}_{\mathrm{it}}+\beta_{6} \mathrm{CRISIS}_{\mathrm{t}}+\mathrm{u}_{\mathrm{ijt}}
$$

Where:

$\mathrm{e}=$ refers to the company "e";

$\mathrm{j}=$ refers to the corporate bond " $\mathrm{j}$ ";

$i=$ refers to the multimarket fund "i";

$\mathrm{t}=$ refers to time;

$\beta=$ coefficients of the variables;

$\% \mathrm{FUND}=$ this is the dependent variable, it represents the percentage of each multimartket fund portfolio invested in each corporate bond;

$B P I=$ independent variable and it represents the Bondholders' Protection Index;

$\mathrm{BPI}^{*} \mathrm{AM}=$ independent variable and it represents the Interaction between BPI and the number of "automatic maturity" clauses;

$\mathrm{CVB}=$ control variables related to the corporate bonds characteristics;

$\mathrm{CVC}=$ control variables related to the companies features;

$\mathrm{CVF}=$ control variables related to the funds characteristics;

VCFM = variáveis de controle correspondentes às características dos fundos multimercados; CRISIS = dummy variable for periods of crisis.

$\mathrm{u}=$ error term.

\section{DESCRIPTIVE STATISTICS}

\subsection{Dependent Variable}

The variable \%FUND indicates the percentage invested in each corporate bond by each fund in the sample. In other words, it represents the multimarket funds interest for corporate bonds.

We can observe in Table 1 that many years had the minimum value equal to zero. These cases correspond to situations in which the value invested in corporate bonds is less expressive when compared to the total net assets of the respective fund. Therefore, the percentage is next to zero. An opposite situation can be observed in the year 2016, in which one fund of the sample invested more than $99 \%$ of its total net assets in a specific corporate bond. This bond was issued by the company Ceb Distribuição S. A. in2015 (due date is 2020). 
Table 1

Descriptive Statistics of the Percentage that the Multimarket Funds Invest in Corporate Bonds

\begin{tabular}{lccccc}
\hline Year & No & Average & SD & Max. & Min. \\
\hline 2009 & 137 & 1.48 & 1.92 & 9.30 & 0.07 \\
2010 & 712 & 1.62 & 1.62 & 12.33 & 0.01 \\
2011 & 1171 & 1.56 & 1.53 & 12.75 & 0.00 \\
2012 & 2489 & 1.31 & 1.42 & 24.67 & 0.00 \\
2013 & 2917 & 1.27 & 1.47 & 23.14 & 0.00 \\
2014 & 3608 & 1.36 & 1.54 & 27.94 & 0.00 \\
2015 & 3660 & 1.41 & 1.80 & 43.00 & 0.00 \\
2016 & 3977 & 1.45 & 2.72 & 99.58 & 0.00 \\
2017 & 4809 & 1.24 & 1.70 & 47.47 & 0.00 \\
Total & 23480 & 1.36 & 1.85 & 99.58 & 0.00 \\
\hline
\end{tabular}

Note. We considered the information of portfolio holdings of each multimarket fund at the end of December of each year.

Source: research database.

Despite the representative case commented on in the previous paragraph, the multimarket funds of the sample allocate on average $1.36 \%$ of their TNA in debentures. In this way, there is a relatively small participation of Brazilian multimarket funds in the acquisition of corporate bonds, even with the significant participation of institutional investors as debentures subscribers in Brazil.

\subsection{INDEPENDENT VARIABLE}

Regarding the independent variable: first, we analyzed the frequency of restricted clauses related to the index (BPI). The results in Table 2 indicated that, on one hand, the most frequently cited clauses are: (i) negligence by the issue companies; (ii) liquidation, dissolution and bankruptcy; and (iii) restrictions related to the modification in the company's structure. All of these three clauses presented a relative frequency higher than $94 \%$. On the other hand, the clauses with the lower frequency are: (i) leverage policy; (ii) stocks emission or amortization; and (iii) lowering in the rating classification. These items had a relative frequency equal or lower to $27 \%$. Table 2 also highlights information about clauses with automatic maturity. Therefore, we can observe that some of the most frequently cited clauses are not necessarily expressed as items that guarantee an immediate payment to the bondholders. For example, clauses related to financial indexes had a relative frequency of $76 \%$, but they were identified as automatic maturity clauses in only $4 \%$ of the cases.

The bondholders' protection index (BPI) reveals the level of protection offered to bondholders, following each bond issued. These clauses represent a way to reduce debt costs and increase companies' value (Smith \& Warner, 1979; Kahan \& Tuchman, 1993), as well as allowing to minimize bankruptcy and mitigate agency conflicts (Jerzemowska, 2006). 
BBR

17

142

Table 2

Frequency of Debentures' Restrictive Clauses

\begin{tabular}{|c|c|c|c|c|c|c|c|c|c|}
\hline \multirow{4}{*}{ Clauses Description } & \multirow{3}{*}{\multicolumn{2}{|c|}{$\begin{array}{c}\text { Non } \\
\text { Identified } \\
\text { Clauses }\end{array}$}} & \multicolumn{6}{|c|}{ Identified Clauses } & \multirow{4}{*}{ Obs } \\
\hline & & & \multirow{2}{*}{\multicolumn{2}{|c|}{ Total }} & \multicolumn{4}{|c|}{ Automatic Maturity? } & \\
\hline & & & & & \multicolumn{2}{|c|}{ No } & \multicolumn{2}{|c|}{ Yes } & \\
\hline & $\mathrm{AF}$ & RF & $\mathrm{AF}$ & RF & $\mathrm{AF}$ & RF & $\mathrm{AF}$ & RF & \\
\hline Dividends Restrictions & 176 & $19.01 \%$ & 750 & $80.99 \%$ & 367 & $39.63 \%$ & 383 & $41.36 \%$ & \\
\hline Capital Reduction & 132 & $14.25 \%$ & 794 & $85.75 \%$ & 397 & $42.87 \%$ & 397 & $42.87 \%$ & \\
\hline $\begin{array}{l}\text { Liquidation, Dissolution and } \\
\text { Bankruptcy }\end{array}$ & 2 & $0.22 \%$ & 924 & $99.78 \%$ & 35 & $3.78 \%$ & 889 & $96.00 \%$ & \\
\hline Modification of Business Essence & 257 & $27.75 \%$ & 669 & $72.25 \%$ & 439 & $47.41 \%$ & 230 & $24.84 \%$ & \\
\hline Modification in the Company's Structure & 50 & $5.40 \%$ & 876 & $94.60 \%$ & 150 & $16.20 \%$ & 726 & $78.40 \%$ & \\
\hline Modification in the Control & 99 & $10.69 \%$ & 827 & $89.31 \%$ & 508 & $54.86 \%$ & 319 & $34.45 \%$ & \\
\hline Assets Sale or Transference & 321 & $34.67 \%$ & 605 & $65.33 \%$ & 416 & $44.92 \%$ & 189 & $20.41 \%$ & \\
\hline Negligence & 1 & $0.11 \%$ & 925 & $99.89 \%$ & 37 & $4.00 \%$ & 888 & $95.90 \%$ & 926 \\
\hline Legal Oblig. and Environmental Permits & 389 & $42.01 \%$ & 537 & $57.99 \%$ & 355 & $38.34 \%$ & 182 & $19.65 \%$ & \\
\hline Financial Indexes & 217 & $23.43 \%$ & 709 & $76.57 \%$ & 669 & $72.25 \%$ & 40 & $4.32 \%$ & \\
\hline Investments & 515 & $55.62 \%$ & 411 & $44.38 \%$ & 192 & $20.73 \%$ & 219 & $23.65 \%$ & \\
\hline Leverage & 787 & $84.99 \%$ & 139 & $15.01 \%$ & 83 & $8.96 \%$ & 56 & $6.05 \%$ & \\
\hline Stocks & 685 & $73.97 \%$ & 241 & $26.03 \%$ & 110 & $11.88 \%$ & 131 & $14.15 \%$ & \\
\hline Rating Classification & 676 & $73.00 \%$ & 250 & $27.00 \%$ & 184 & $19.87 \%$ & 66 & $7.13 \%$ & \\
\hline Merger, Split and Incorporation & 135 & $14.58 \%$ & 791 & $85.42 \%$ & 392 & $42.33 \%$ & 399 & $43.09 \%$ & \\
\hline
\end{tabular}

Note. AF: Absolute Frequency; RF: Relative Frequency.

Source: research database.

The results in Table 3 suggest that, on average, the value of BPI was 0.6731 . The maximum value was 1.000 and it indicates that the sample includes at least one debenture indenture that has all the clauses. Regarding the minimum value of 0.0667 , it indicates that all debenture indentures of the sample have at least one of the clauses that comprise the BPI.

Table 3

Descriptive Statistics of BPI

\begin{tabular}{llllll}
\hline Year & No & Average & SD & Max. & Min. \\
\hline 2009 & 53 & 0.6352 & 0.1369 & 0.9333 & 0.3333 \\
2010 & 99 & 0.6290 & 0.1337 & 0.9333 & 0.3333 \\
2011 & 90 & 0.6696 & 0.1374 & 0.8667 & 0.2000 \\
2012 & 164 & 0.6134 & 0.1686 & 1.0000 & 0.2667 \\
2013 & 107 & 0.6430 & 0.1374 & 0.9333 & 0.2667 \\
2014 & 105 & 0.6984 & 0.1542 & 0.9333 & 0.1333 \\
2015 & 82 & 0.7252 & 0.1399 & 0.9333 & 0.2667 \\
2016 & 60 & 0.6878 & 0.1640 & 0.9333 & 0.2000 \\
2017 & 166 & 0.7450 & 0.1353 & 0.9333 & 0.0667 \\
Total & 926 & 0.6731 & 0.1536 & 1.0000 & 0.0667 \\
\hline
\end{tabular}

Source: research database. 


\subsection{Control Variables}

Regarding the characteristics of corporate bonds, Table 4 indicates that they usually have a due date of up to three years $(88.84 \%)$, have restrict efforts $(73.47 \%)$, and that their remuneration is indexed to the ID rate (73.04\%). Moreover, the frequency of incentivized corporate bonds is low $(7.23 \%)$ and they generally do not have real guarantee.

Table 4

Corporate Bonds Characteristics

\begin{tabular}{lcccccc}
\hline \multirow{2}{*}{ Characteristics } & \multicolumn{2}{c}{ Yes } & \multicolumn{2}{c}{ No } & \multicolumn{2}{c}{ Total } \\
& AF & RF & AF & RF & AF & RF \\
\hline Restrict Efforts & 2752 & $73.47 \%$ & 994 & $26.53 \%$ & & \\
Incentivized Corporate Bonds & 271 & $7.23 \%$ & 3475 & $92.77 \%$ & & \\
Corporate Bonds Guarantee (Real) & 614 & $16.39 \%$ & 3132 & $83.61 \%$ & 3746 & $100 \%$ \\
Maturity <= 3 years & 3328 & $88.84 \%$ & 418 & $11.16 \%$ & & \\
Rate of Remuneration (ID) & 2736 & $73.04 \%$ & 1010 & $26.96 \%$ & & \\
\hline
\end{tabular}

Note. AF: Absolute Frequency; RF: Relative Frequency.

Source: research database.

As presented in Table 5, on average, the companies of the sample have a profitability index of $13 \%$ and $8 \%$ of investments expansion. The average size, measured by the natural logarithm of companies' market value, is 15.84 on average. Based on the results for the variable book-tomarket, we can observe that firms tend to present a market value higher than their book value, since the average index was 0.8260 .

Table 5

Characteristics of the Companies that Issued Corporate Bonds Acquired by the Funds of the Sample.

\begin{tabular}{lccccc}
\hline Variables & No & Average & SD & Max. & Min. \\
\hline Profitability & 23480 & 0.1351 & 0.2139 & 0.5959 & -1.9294 \\
Investiment & 23480 & 0.0786 & 0.2767 & 2.1586 & -0.3087 \\
Size (NL of Market Value) & 23480 & 15.8370 & 0.9793 & 19.1910 & 12.8096 \\
Book-to-market & 23480 & 0.8260 & 0.6545 & 3.3099 & 0.0805 \\
\hline
\end{tabular}

Source: research database.

The sample of this study comprises 1753 multimarket funds. The size of the funds included in the sample, measured by the natural logarithm of their TNA, corresponds to 18.03, as described in Table 6.

Table 6

Characteristics of the Multimarket Funds of the Sample

\begin{tabular}{llllll}
\hline Variables & No & Average & SD & Max. & Min. \\
\hline NL(TNA) & 23480 & 18.0331 & 1.2798 & 21.9142 & 15.4690 \\
Management Fee & 23480 & 0.4267 & 0.6199 & 5.0000 & 0.0000 \\
Fund's Age & 23480 & 9.0631 & 4.6806 & 22.4917 & 0.7750 \\
Funds of Funds & 23480 & 0.0341 & 0.1814 & 1.0000 & 0.0000 \\
Performance Fee & 23480 & 0.1695 & 0.3752 & 1.0000 & 0.0000 \\
\hline
\end{tabular}

Source: research database. 
BBR

17

144

The management fees are $0.43 \%$ by year, on average, and the age of the funds is 9 years (on average). Only $3.41 \%$ of the sample are funds of funds and about $16.95 \%$ of the samples correspond to funds that have performance fees.

\section{RESULTS AND DISCUSSION}

We use linear regression with pooled data, considering standard errors corrected by White's robust matrix (White, 1980). Missing values in the variables of companies features and funds characteristics were excluded. We also employed the winsorizing procedure at $1 \%$ in these variables, as well as in the dependent variable (\%FUND). After the exclusion of missing values, the final database was comprised of 23480 observations.

Two models were estimated. Model 1 considers the interaction between BPI and the dummy variable for debentures indentures with a large number of automatic maturity clauses. In Model 1 , the median is the cutpoint to classify indentures with large number of automatic maturity clauses in the dummy variable. Regarding Model 2, it also considers the interaction between BPI and the dummy for a number of automatic maturity clauses; however, in this case, the cutpoint is the third quartile to classify indentures with the large number of automatic maturity clauses. Both models have the same control variables and dummy variables for industry sector (following Economatica $^{\circledast}$ classification) and year. The median of the number of automatic maturity clauses was 5.9 and the third quartile was 7.9; in other words, half of the indentures had five or more clauses with automatic maturity and a quarter of the indentures had seven or more clauses with automatic maturity.

The results available in Table 7 indicate that many variables showed a significant relationship with the percentage invested by the funds in indentures. These results support $\mathrm{H}_{1}$ at $1 \%$ of significance, so we reject the null hypothesis of the absence of relationship between the variable BPI and the variable \%FUND. In other words, this result indicates that the variable BPI has a positive effect in the percentage that multimarket funds allocate in debentures. The positive relationship observed between these variables corroborates the study of Nash, Nette and Poulsen (2003), since the result suggests that bondholders consider indentures' restrictive clauses as a mechanism to mitigate a negligent behavior of managers. Therefore, there is an evidence about the relevance of BPI, as it involves clauses related to operational aspects and projects implemented, which also corroborates the study of Jensen and Meckling (1976). Moreover, the result highlights that the use of restrictive clauses is relevant especially in environments of incomplete markets, as Sheng (2005) pointed out.

Based on the results of this study, the flexible and adaptable structure of debentures (Saito, Sheng, \& Bandeira, 2007), together with the possibility of reducing agency conflicts between bondholders and shareholders (Smith \& Warner, 1979; Billet, King, \& Mauer, 2007), reduce the possibility of bondholders expropriation (Silva, Saito, \& Barbi, 2013), attracting the interest of institutional investors to buy such bonds. The effect of the interaction between BPI and the dummy variable, based on the number of automatic maturity clauses, was significant only for debentures indentures that have a large number of such clauses (above the third quartile). This result indicates that the positive effect of BPI on the dependent variable is higher when considering the indentures that have a large number of automatic maturity clauses. The positive effect of this interaction can be evidence that fund managers are also observing measures to protect themselves in the case that invested companies start to face difficulties that might: (i) damage their bonds profitability; or (ii) affect the redemption of the value invested in bonds acquisition. 
Table 7

Results of the Linear Regression Model (with Pooled Data)

\begin{tabular}{lllllll}
\hline Variables & Model $(1)$ & & & Model $(2)$ & \\
& Beta & P-value & Sig & Beta & P-value & Sig \\
\hline BPI & 0.8115 & 0.000 & $* * *$ & 0.7331 & 0.000 & $* * *$ \\
BPI*AM(median) & 0.0136 & 0.810 & & & & \\
BPI*AM(3Quart.) & & & & 0.1102 & 0.015 & $* *$ \\
REST & -0.1027 & 0.017 & $* *$ & -0.1016 & 0.010 & $* *$ \\
INCENT & 0.0576 & 0.087 & $*$ & 0.0637 & 0.053 & $*$ \\
MAT & -0.0318 & 0.408 & & -0.0268 & 0.480 & \\
REAL & -0.0973 & 0.288 & & -0.1248 & 0.169 & \\
RATE & -0.2714 & 0.000 & $* * *$ & -0.2800 & 0.000 & $* * *$ \\
NM & -0.0575 & 0.111 & & -0.0571 & 0.107 & \\
CRISIS & -0.1873 & 0.248 & & -0.1778 & 0.268 & \\
INV & 0.1258 & 0.092 & $*$ & 0.1232 & 0.099 & $*$ \\
BTM & 0.0156 & 0.556 & & 0.0083 & 0.752 & \\
PROF & -0.0289 & 0.715 & & -0.0376 & 0.635 & \\
SIZE(company) & 0.1524 & 0.000 & $* * *$ & 0.1542 & 0.000 & $* * *$ \\
NL(Funds TNA) & -0.3312 & 0.000 & $* * *$ & -0.3314 & 0.000 & $* * *$ \\
FoF & 0.1546 & 0.019 & $* *$ & 0.1540 & 0.020 & $* *$ \\
MGMFee & 0.0531 & 0.002 & $* * *$ & 0.0528 & 0.002 & $* * *$ \\
PERFFee & 0.1610 & 0.000 & $* * *$ & 0.1621 & 0.000 & $* * *$ \\
Age & -0.0330 & 0.000 & $* * *$ & -0.0329 & 0.000 & $* * *$ \\
_const & 4.9649 & 0.000 & $* * *$ & 4.9626 & 0.000 & $* * *$ \\
No & 23480 & 23480 & & & & \\
R ${ }^{2}$ & 0.0954 & 0.0956 & & & & \\
R (adjusted) & 0.0939 & 0.0941 & & & & \\
\hline
\end{tabular}

Note. Results of the linear regression models (Equation 2). The asteristics indicate the level of significance: ${ }^{*} \mathrm{p}<$ $0.10{ }^{* *} \mathrm{p}<0.05{ }^{* * *} \mathrm{p}<0.01$. The models include dummy variables for industry sector and year, also considering the White's Robust Matrix. Model 01 presented an average VIF of 1.28 and Model 02 presented an average VIF of 1.26.

Source: research database.

On one hand, the effect of the variable INCENT on the $\% \mathrm{FUND}$ was positive and significant at $10 \%$. On the other hand, the variable for corporate bonds issued with restrict efforts presented a negative effect on the dependent variable. The rate of remuneration for debentures indexed to ID rate was also significant at $1 \%$, suggesting that bonds indexed to ID rate tend to be less attractive to the funds sampled. Regarding the variables REAL and MAT, their effects were not significant.

The effect of the variable NM on the dependent variable was different to what would be expected, since the literature points out that corporate governance has an important role to expand the capital market and the market of corporate bonds (Ripamonti \& Kayo, 2016).

The variables SIZE and INV showed a positive and significant effect (at 10\% and 1\% respecivelly) in the variable \%FUND. These results corroborate the previous research of Sobrinho (2016) and Fama and French $(1993,2015)$, since they highlight company-related variables which are 
BBR

17

146

relevant to understanding funds' allocation. Regarding the other two company-related variables (PROF and BTM), and the variable CRISIS, their effect was not significant.

In relation to the fund-related variables, at least at a 5\% level of significance, the variables FoF, MGMFee and PERFFee presented a positive effect on the variable \%FUND. The effect of the variables Age and Fund's Size (NL-Funds TNA) was negative and significant at $1 \%$. These results reinforce the literature on investment funds that consider these variables, since they were also important to analyze the allocation of investment funds in corporate bonds.

\section{CONCLUSION}

This paper aimed at creating a bondholders' protection index, which involves debentures' restrictive clauses, and at identifying this index relevance, especially for institutional investors who are one of the main subscribers in Brazil. Covenants are an alternative for mitigating conflicts among bondholders, shareholders, and managers. Therefore, a BPC reflects the degree of bondholders' protection in Brazil, not only for contemplating clauses, which indicate some rules that companies must follow, but also because they involve restrictions, for example, regarding investment, financing and dividend policies.

Concerning covenants, we noted that the most common restrictive clauses refer to the potential negligent performance of a company, liquidation, dissolution or bankruptcy, and restrictions related to company structure. In addition, the less common ones involve indebtedness' policy, issuance, or amortization of shares and downgrading company's rating level.

In this paper, we created the BPI, and explored its interactions with a number of "automatic maturity" clauses in indentures. On average, the BPI corresponded to 0.6731 , and we noted cases of companies that meet all the requirements evaluated with BPI. We point out that, although mutual funds are one of the main subscribers in Brazil, on average only $1.36 \%$ of multimarket funds' portfolios are allocated in debentures.

These results are in line with our $\mathrm{H}_{1}$ hypothesis at the level of $1 \%$ of significance, which suggests that the higher the BPI, the greater the multimarket funds' interest for corporate bonds. Hence, this study responds to the proposed goal and contributes to the literature for recommending the creation of a bondholders' protection index, which focuses on the Brazilian debentures' indentures features. Therefore, BPI reflects the level of protection that Brazilian debentures guarantee to creditors, as a way of mitigating issuing companies' negligent behavior. We also noted for indentures with a high number of clauses with "automatic maturity" (above the 3rd quartile), the positive effect is even greater.

We also highlighted how this study would contribute to multimarket funds literature: analyzing funds allocation in corporate bonds. Taking into account empirical contributions, this research involved analysis of debentures, which are the most representative securities in the Brazilian financial market. Moreover it is also important for regulatory agencies, such as ANBIMA, especially in proposes of debentures' indentures standardization.

Nonetheless, this paper presents limitations related to the number of comprised companies in the hypothesis test. Despite this, the study includes issued debentures by companies not listed in B3, although econometric models analysis involved only listed companies.

We point out that issuing companies can already have prior knowledge related to institutional investors' intention and preferences regarding debentures' acquisition with specific restrictive clauses, which may grant them greater protection and risk minimization. This guarantee would be given because covenants represent an anticipation of managers and shareholders for potential 
opportunist performance. In this way, the proposed relationship in this paper can present some simultaneity bias, which can be better investigated in future studies involving instrumental variable, which can capture the possible adjustments in debentures' indentures, as issued by the same companies, over time. Therefore, for future studies, we suggest the adoption of an instrumental variable, as well as the use of another estimation method for analyzing possible effects and unfolding of the clauses present in debentures' indentures.

Moreover, future studies on different topics covered in this research can be developed, as follows: (i) BPI; (ii) Debentures' Indentures; and (iii) Investment Funds. Concerning BPI, we suggest to expand the analysis of this index's influence in institutional investor's interest for debentures acquisition. In addition, we recommend associating this index with a risk-adjusted return measure in order to better understand the impact on bondholders' interest. Regarding debentures' indentures, in view of the fact that the literature and CVM 404 Instruction highlight the importance of detailing the restrictive clauses, we propose the investigation of readability for these clauses and the relevance of legibility for institutional investors. Finally, regarding investment funds, we indicate the verification of funds' regulations, prospectuses, and blades, for understanding if there is any evidence that justify the low percentage of funds' portfolios allocated in corporate bonds.

\section{REFERENCES}

Amin, G. S., Kat, H. M. (2003). Hedge fund performance 1990-2000: do the 'money machines' really add value? Journal of Financial and Quantitative Analysis, 38(2), 251-274. https://doi. org/10.2307/4126750

Associação Brasileira das Entidades dos Mercados Financeiro e de Capitais [Brazilian Financial and Capital Markets Association]. (2015). Classificação de fundos-visão geral e nova estrutura [Funds' classification - general vision and new structure]. Retrieved from http://www.anbima. com.br/data/files/E3/62/8C/0B/242085106351AF7569A80AC2/NovaClassificacaodeFundos_ PaperTecnico_1_.pdf

Associação Brasileira das Entidades dos Mercados Financeiro e de Capitais [Brazilian Financial and Capital Markets Association]. (2017). Guia de orientação para escrituras de debêntures [Orientation Guide for Debentures Indentures]. Retrieved from http:// www.anbima.com.br/data/files/60/87/91/E9/602085106351AF7569A80AC2/ GuiadeOrientacaoparaEscriturasdeDebentures-29-10-15_1_.pdf

Associação Brasileira das Entidades dos Mercados Financeiro e de Capitais [Brazilian Financial and Capital Markets Association]. (2018). Anuário da Indústria de Fundos de Investimento 2010 a 2018 [Yearbook of Investment Funds Industry]. Retrieved from http://cef.fgv65.br/ anuario-da-industria-de-fundos

Associação Brasileira das Entidades dos Mercados Financeiro e de Capitais [Brazilian Financial and Capital Markets Association]. (2018). Boletim de mercado de capitais ANBIMA - 2010 a 2018 [ANBIMA Capital Markets Bulletin - 2010 to 2018]. Retrieved from http://www. anbima.com.br/pt_br/informar/relatorios/mercado-de-capitais/boletim-de-mercado-de-capitais/ boletim-de-mercado-de-capitais.htm

Associação Brasileira das Entidades dos Mercados Financeiro e de Capitais [Brazilian Financial and Capital Markets Association]. (2018). Consolidado Histórico Fundos de Investimento [Consolidated Historical of Investment Funds]. Retrieved from http://www.anbima.com.br/ pt_br/informar/estatisticas/fundos-de-investimento/fi-consolidado-historico.htm 
BBR

17

148

Beaver, W. H. (1998). Financial Reporting: an accounting revolution. New York: Prentice Hall.

Billet, M. T., King, T. D., \& Mauer, D. C. (2007). Growth opportunities and the choice of leverage, debt maturity, and covenants. The Journal of Finance, 62(2), 697-730. https://doi. org/10.1111/j.1540-6261.2007.01221.x

Bono Milan, P. L. A., \& Eid Jr., W. (2014). Elevada rotatividade de carteiras e o desempenho dos fundos de investimento em açóes. Revista Brasileira de Finanças, 12(4), 469-497.

Bono Milan, P. L. A., \& Eid Jr., W. (2017). Um retrato dos fundos de investimento no Brasil. GV Executivo, 16(1), 20. https:/doi.org/10.12660/gvexec.v16n3.2017.70709

Bradley, M., \& Roberts, M. R. (2015). The structure and pricing of corporate debt covenants. Quarterly Journal of Finance, 5(2), 1-37. https://doi.org/10.1142/S2010139215500019

Bragança, G. G. F., Pessoa, M. S., \& Souza, G. M. (2015). Evolução recente do mercado de debêntures no Brasil: as debêntures incentivadas. Instituto de Pesquisa Econômica Aplicada. Brasília, Rio de Janeiro: Ipea.

Carvalho, P. S. (2017). Perfil e determinantes do mercado de debêntures no Brasil no periodo de 2004-2014 (PhD Dissertation in Economics). Universidade Federal do Rio de Janeiro, Rio de Janeiro.

Chava, S., Kumar, P., \& Warga, A. (2010). Managerial agency and bond covenants. The Review of Financial Studies, 23(3), 1120-1148. https://doi.org/10.1093/rfs/hhp072

Christensen, P. O., \& Feltham, G. A. (2005). Economics of accounting (v. II). Performance Evaluation. Springer, New York.

Devos, E., Rahman, S., \& Tsang, D. (2017). Debt covenants and the speed of capital structure adjustment. Journal of Corporate Finance, 45(1), 1-18. https://doi.org/10.1016/j. jcorpfin.2017.04.008

Fama, E. F., \& French, K. R. (1993). Common risk factors in the returns on stocks e bonds. Journal of Financial Economics, 33(1), 3-56. https://doi.org/10.1016/0304-405X(93)90023-5

Fama, E. F., \& French, K. R. (2015). A five-factor asset pricing model. Journal of Financial Economics, 116(1), 1-22. https://doi.org/10.1016/j.jfineco.2014.10.010

Ghouma, H. (2017). How does managerial opportunism affect the cost of debt financing? Research in International Business and Finance, 39(1), 13-29. https://doi.org/10.1016/j.ribaf.2016.07.007

Greene, W. H. (2002). Econometric analysis. New Jersey: Pearson Education, Prentice Hall.

International Organization of Securities Comission. (2002). Development of corporate bond markets in the emerging markets, 2002. Madrid: Iosco. Retrieved from http://goo.gl/3ImYL5

Jensen, M. C., \& Meckling, W. (1976). Theory of the firm: managerial behavior, agency costs and capital structure. Journal of Financial Economics, 3(4), 305-360. https://doi.org/10.1016/0304$405 \mathrm{X}(76) 90026-\mathrm{X}$

Jerzemowska, A. M. (2006). The main agency problems and their consequences. Acta Oeconomica Pragensia, 14(3), 9-17. https://doi.org/10.18267/j.aop.73

Kahan, M. (1995). The qualified case against mandatory terms in bonds. Northwestern University Law Review, 89(2), 565-622.

Kahan, M., \& Tuchman, B. (1993). Do bondholders lose from junk bond covenant changes? The Journal of Business, 66(4), 499-516. https://doi.org/10.1086/296615 
Konraht, J. M., \& Vicente, E. F. R. (2017). Determinantes da utilização de covenants contábeis nas debêntures emitidas pelas empresas listadas na B3. XVII USP International Conference in Accounting, São Paulo.

Liu, C. L., Dai, T. S., \& Wang, C. J. (2016). Evaluating corporate bonds and analyzing claim holders' decisions with complex debt structure. Journal of Banking \& Finance, 72(1), 151-174. https://doi.org/10.1016/j.jbankfin.2016.05.007

Malaquias, R. F., \& Eid Jr., W. (2014). Fundos multimercados: desempenho, determinantes do desempenho e efeito moderador. Revista de Administração Mackenzie, 15(4), 135-163. https:// doi.org/10.1590/1678-69712014/administracao.v15n4p135-163

Malaquias, R. F., \& Mamede, S. P. N. (2015). Efeito calendário e finanças comportamentais no segmento de fundos multimercados. Revista de Administração Contemporânea, 19(6), 98-116. http://dx.doi.org/10.1590/1982-7849rac20152062

Malaquias, R. F., \& Pontes, G. A. (2018). Restriçóes de liquidez em fundos de investimentos: uma resposta aos vieses comportamentais? Brazilian Business Review, 15(4), 382-390. https:// doi.org/10.15728/bbr.2018.15.4.5

Milani, B., \& Ceretta, P. S. (2013, January/March). Efeito tamanho nos fundos de investimento brasileiros. Revista de Administração da UFSM, 6(1), 119-138. https://doi. org/10.5902/198346593607

Nash, R. C., Netter, J. M., \& Poulsen, A. B. (2003). Determinants of contractual relations between shareholders and bondholders: investment opportunities and restrictive covenants. Journal of Corporate Finance, 9(2), 201-232. https://doi.org/10.1016/S0929-1199(02)00007-X

Paiva, E. V. S., \& Savoia, J. R. F. (2009). Pricing corporate bonds in Brazil: 2000 to 2004. Journal of Business Research, 62(1), 916-919. https://doi.org/10.1016/j.jbusres.2008.10.012

Paula, L. F., \& Faria Jr., J. A. (2012). Mercado de títulos de dívida corporativa privada no Brasil: aspectos estruturais e evolução recente. Revista de Economia Contemporânea, 16(1), 107-137. http://dx.doi.org/10.1590/S1415-98482012000100006

Qi, Y., Roth, L., \& Wald, J. K. (2011). How legal environments affects the use of bond covenants. Journal of International Business Studies, 42(1), 235-262. https://doi.org/10.1057/jibs.2010.52

Ripamonti, A., \& Kayo, E. K. (2016). Corporate governance and capital structure in Brazil: stock, bonds and substitution. Revista de Administração Mackenzie (RAM), 17(5), 85-109. http://dx.doi.org/10.1590/1678-69712016/administracao.v17n5p85-109

Rochman, R. R., \& Eid Jr., W. (2006). Fundos de investimento ativos e passivos no Brasil: comparando e determinando os seus desempenhos. XXX Encontro da Associação Nacional de Pós-Graduação e Pesquisa em Administração (ENANPAD), Salvador.

Saito, R., Sheng, H. H., \& Bandeira, M. L. (2007). Governança corporativa embutida nas escrituras de debêntures emitidas no Brasil. Revista de Administração da USP - RAUSP, 42(3), 580-292.

Saraiva, A., \& Sales, R. (2017). PIB do Brasil cai 7,2\% em dois anos, pior recessão desde 1948 [Brazil's GDP falls $7.2 \%$ in two years, the worst recection since 1948]. Valor. Retrieved from http:// www.valor.com.br/brasil/4890366/pib-do-brasil-cai-72-em-dois-anos-pior-recessao-desde-1948

Sheng, H. H. (2005). Ensaios sobre emissóes de corporate bonds (debêntures) no mercado brasileiro (PhD Dissertation in Business Management). Escola de Administração de Empresas de São Paulo, Fundação Getúlio Vargas, São Paulo. 
BBR

17

150

Silva, V. A. B., Saito, R., \& Barbi, F. C. (2013). The role of bond covenants and short-term debt: evidence from Brazil. BAR - Brazilian Administration Review, 10(3), 323-346. http://dx.doi. org/10.1590/S1807-76922013000300006

Smith, C., \& Warner, J. (1979). On financial contracting. Journal of Financial Economics, 7(2), 117-161. https://doi.org/10.1016/0304-405X(79)90011-4

Sobrinho, E. J. (2016). Potenciais efeitos dos dividendos na composição e na performance de fundos de açôes no Brasil (Master's Degree Thesis in Accounting Sciences). Universidade Federal de Uberlândia, Uberlândia.

White, H. (1980). A heteroskedasticity-consistent covariance matrix estimator and a direct test for heteroskedasticity. Econometrica Journal of the Econometric Society, 48(4), 817-838. https:// doi.org/10.2307/1912934

\section{FINANCIAL SUPPORT}

This study was financed in part by the Coordenação de Aperfeiçoamento de Pessoal de Nível Superior - Brasil (CAPES) - Finance Code 001. Rodrigo F. Malaquias also would like to thank the Fundação de Amparo à Pesquisa do Estado de Minas Gerais (FAPEMIG), Finance Code APQ-01265-14. 